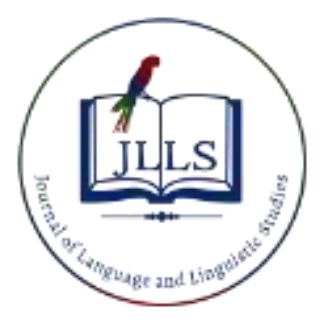

Available online at www.jlls.org

JOURNAL OF LANGUAGE AND LINGUISTIC STUDIES

ISSN: 1305-578X

Journal of Language and Linguistic Studies, 16(1), 166-184; 2020

\title{
How does "to what gender and status one talks" govern the speaker's strategy in keeping on their conversation?
}

\author{
Giyoto Giyoto $^{\text {a }} 1$ (D), Novianni Anggraini ${ }^{\mathrm{b}}$ (D) , Elen Inderasaric ${ }^{\mathrm{c}}$ (D) Luthfie Arguby Purnomo ${ }^{\mathrm{d}}$ \\ ${ }^{a}$ Institut Agama Islam Negeri Surakarta, Jl. Pandawa Pucangan Kartasura, Sukoharjo 57161, Indonesia \\ ${ }^{b}$ Institut Agama Islam Negeri Surakarta, Jl. Pandawa Pucangan Kartasura, Sukoharjo 57161, Indonesia \\ ${ }^{c}$ Institut Agama Islam Negeri Surakarta, Jl. Pandawa Pucangan Kartasura, Sukoharjo 57161, Indonesia \\ ${ }^{d}$ Institut Agama Islam Negeri Surakarta, Jl. Pandawa Pucangan Kartasura, Sukoharjo 57161, Indonesia
}

\begin{abstract}
APA Citation:
Giyoto, Novianni, A., Elen, I., \& Luthfie, A., P. (2020). How Does “To what gender and status one talks" govern the speaker's strategy in keeping on their conversation? Journal of Language and Linguistic Studies, 16(1), 166-184. Doi: 10.17263/j1ls.712691

Submission Date: 08/16/2019

Acceptance Date: 10/17/2019
\end{abstract}

\begin{abstract}
"To what gender and status one talks" governs more the speaker, in deciding their culturally and socially accepted strategy in conversation, than "who talks"; as the airport runway dictates the pilot's landing strategy. This paper, employing conversational analysis, tries to explore how the gender and social status of the audience dictate the speaker's speech acts and moves in Muslim formal conversation in three functional topical units composed of 107 acts of directive, assertive, commisive, expressive, rogative, and 103 moves of initiations, responses, and follow ups. The finding shows that, to all female students, a male initiates and controls the conversation for materializing his social power by having more directive acts and initiation moves. To the high female, Low male uses assertive and response. While the female, regardless the social status and gender of the audience, uses assertive acts and response moves to support the interaction and social togetherness. The findings imply that the object to whom one talks is more crucial in describing the conversation strategy.
\end{abstract}

(C) 2020 JLLS and the Authors - Published by JLLS.

Keywords: to what gender and status; control; conversation; strategy; materialize; power

\section{Introduction}

The social status and gender background understanding of the audience dictates the types of the strategy and the forms of speech used by the speaker. The understanding influences the level of intimacy and tolerance of the role relationship among the participants that enrich the depth of the generated meaning. The language behavior cannot be studied beyond its underlying social background because its meaning is governed by some outside embedded social and cultural variables, such as aspect of who speaks, to whom, the speech form, aim, situation context in which the interaction takes place.

\footnotetext{
${ }^{1}$ Giyoto. Tel.: +62-081-228-410801

E-mail address: p.giyoto@gmail.com
} 
Conversational strategies, with its linguistic forms (language behavior), are arranged to fulfill the cognitive or intellectual need, affective need, and psychological need (mental satisfaction). A certain strategy can be fulfilling the need of only one or a blend of more than one need.

There should be more studies which analyze clearly to what gender one talks because the strategy of conversation is dependent to whom one talks, including the audience status and gender. The analysis based on the object to whom one talks is very crucial in describing the conversation strategy one takes, supposed that the strategy of pilot in landing their airplane is dependent on the runway of the airport, in which the runway condition of the airport dictates the pilot strategy of landing. This article tries to analyze the pattern of interplay between the gender and social status of the speaker-audience, based on the object/to whom of the talk is addressed in cross gender conversation among students of state Islamic institute in Surakarta Indonesia.

\section{I. Literature review}

The Javanese gender perceptions and expectations have been cumulatively shaped by the education, religion, and social cultural norms since their childhood. Female and male have different ways of perceiving, interpreting, responding, which influence their conversational strategies (Giyoto, 2013). These different worldviews are also materialized and maintained in their conversational strategy. The analysis of conversation, recently, has discussed much on its structure in which intersects the social backgrounds of the speakers and setting, as in: job, age, economic status, social status, and education level or the like: conversation analysis of: among children (Kidwell in Sidnell and Stivers, 2013), medicine (Gill and Maynard, 2006), classroom (Gardner in Sidnell and Stivers, 2013), Courtroom (Komter in Sidnell and Stivers 2013), psychotherapy (Perakyla, Antaki, Vehvilainen, and lauder 2008b). From their conversation strategy, there are many gender studies focusing more on what gender of the speaker (Who) than to what gender (to whom) one talks, in which the reports do not clarify the audience gender attributes, as in: (1) Stevens, Lehmann, Cooper and Whitehouse (2008) reporting that women made more questions, less conflict, less directives than man and used fewer declarative statements; (2) Smith and Dykann (2010) exploring that men has equal language styles in which men are not more directive than women; (3) Myaskovisky, Unikel and Dew (2005) saying that gender moderates the effect of solo status on the amount of talking in the groups and solo women were less talkative than women in the majority, whereas solo men were more talkative than men in majority; (4) Wheelan and Verdi (1992) investigating the types of verbal contributions made by man and woman, over time, in mixed groups, in which men are more task-oriented and women are more maintenance-oriented in group discussion in a 30-60 minutes session; (5) Basow and Rubenfeld (2003) searching the gender and gender-typing interaction styles and finding that women are, overall, more expressive, tentative, and polite in conversation, while men are more assertive, and power-seeker; (6) Baker (2013) saying that the word 'woman' is perceived as being not as adult as the word 'man' qualitatively; (7) Maltz dan Borker in Wardhaugh (1993, p.320) repaorting that male makes more interruptions, challenge or arguments, initiations and more dictating; (8) Johnson and Ensslin (in Baker, 2013) repoting that the male language uses tends to be positively evaluated, as aesthetically pleasing, associated with being "plain-talking' or taboo-breaking but female language uses were less likely positively.

Barbieri (2008, p.58) said that sociolinguistics is the study of the relationship between language and society which concerns with the correlation between language variation and social variables, such as speaker sex, socioeconomic status, age, and race. Tannen (1995, p.138) said that communication isn't as simple as saying what speaker means but how speaker says what he means is crucial because using a language is a learned behavior; how we talk and listen are deeply influenced by cultural expectations. Therefore, one of the important topics that has engaged the minds of many sociolinguists in recent years is the connection among the structure and the use of languages, the social roles of the gender, and 
participant social status. The field of language and gender is one of the most dynamic in sociolinguistics. Gender, on the other hand, is a social property: something acquired or constructed through people's relationships with others and through an individual's adherence to certain cultural norms and prescriptions. This social property influences how to behave socially and culturally. Kiesling (in Holmes and Mayerhoff, 2003, p.531) proved that there are many studies which have proven that the sex identity of an individual can influence judgments on mental, personality traits, achievements, emotional experience, or power. It is said that males and females are born into the same world but they are socialized and live in different cultural worlds.

The gender dominance in interaction, as the materialization of power, has been shaped from the family between sister-brother, father-mother, and play group. This has been culturally sustained and finally stereotyped, specialized and differentiated through verbal representation as presented by Phlips (in Holmes and Meyerhoff, 2003, p.269), in which verbal representation is prominent in the public sphere. Lakoff (1975) emphasized that the gender stereotype is closely related to the ideologies about gender in society. Some communities make male have more social power than female, the same as the power of higher education, profession, religiosity, race and caste. Cameron (in Holmes and Meyerhoff, 2003, p.473) said that Gender stereotypes which are closely based on gender ideology generate naturalized gender differences to sustain the hegemonic male dominance and female subordination, which are parallel to the male's power and female's powerless. Talbot (in Holmes and Mayerhoff, 2003, p.468) said that, in patriarchal social order manifests, male uses the strategy of dominating female through the use of language patterns, as claimed by Dominance Approach. The different ways of using the language is the male privilege. They form the different ways (asymmetry) from adulthood and behave accordingly to which one belongs to male and female styles. It seems, in general, that all known societies appear to use language as one of the means of marking out gender differences; therefore, numerous observers have described woman speech as being different from that of men (Tannen, 1990). Freed (in Holmes and Meyerhoff, 2003, p.473) agreed that a particular verbal strategy associated with gender is not in a vacuum but it is an integral part of the power arrangements between men and women in societies around the world. This is realized and sustained through the social interaction, including through the strategy of the conversation. There have been proved by many researches that gender's power is materialized through the use of language based on the comparison of frequency in interruption, turn-taking, overlapping, and the spoken word total between male and female (Coats 2004, Itakura, 2000, West and Ziimmerman, 1998, 1983, Swacker, 1979, Eakins and Eakins, 1978). They said that male has and sustains higher power than the female by having more interruptions, turns, words, and initiations. 'The researches of male dominance patterns in verbal interaction over females had been popularized by Lakoff (1975) and Tannen (1995). Male typically interrupts more often the woman turns and woman needs to devote greater effort than men to get attention for their turns. Stanworth (1983), in her research in an experimental classroom interaction in cross gender, has also early proved that the cultural sustainability of the dominance strengthens that male had hegemonic dominance and female had subordinate place.

Interactional dominance was firstly as the constant interruptions to the other participants, before being described as patterns of general controls in asymmetric distribution (Itakura, 2000, p.3). Tannen (1994) defined that dominance is a tendency of a speaker to control the other speakers' actions over the course of interaction. The power of dominating in verbal interaction is multidimensional construct which is composed of sequence, participation, and quantity dimensions (Itakura, 2000, p.4). Sequence dimension is a trend of a certain participant for controlling other participant in the course of initiation and response, which was called before as move according to the hierarchy of interaction components presented by Sinclair and Coulthard (1975). Participatory dominance is controlling others by interrupting and overlapping while quantity dominance is spoken word number by a speaker for which 
he needs more time in his turn. The dominance is not only manifested on how active the participant is but also on what types of acts are taken in representing the power. Gunarsson (1997) said that the dominance is manifested through the choice of acts, in which directive act has higher degree of power than assertive, commissive, rogative, expressive one (see Sinclair and Coulthard, 1975). On the assumption that syntactic phrasing and speech act type indicate different power strategies, the texts were analyzed for different types of request formulations: direct request, indirect requests, and commands. Tannen (1990) argued that man discourse has assertive and competitive features, whereas woman is supportive and relational, leading to the distinction between male "report talk" and female "rapport talk". Tannen $(1990,1995)$, following the line of this research, studied the impact of socialization on women and men and described stereotypical feminine and masculine communication patterns. Her framework of female/male communication indicates that females are generally socialized to feel a primary need for connection while males are generally socialized to feel a need for status. To meet their need for connection, females create intimacy with others, while males meet their need for status by establishing distance or independence from others.

Carli (1990) has also suggested that different norms may have been established for men and women, affecting speech style perceptions. For instance, low-status persons, including women, characterized by a kind of powerless speech style, generally appeal to intensifiers (e.g., so, very), hedges (I think, kind a), hesitations (uh, well), etc. as linguistic devices to secure their social position (Erickson, Lind, Johnson, and O'Barr 1978). Nyamekye and Yarney (2015) reported that woman's behavior in Yendi Northern Gana is monitored and controlled by men either the men are of family or other relations". Women cannot be away from being a housewife who serves and responsible for the family daily need as well as household activities.

\subsection{Research questions}

Referring to the above theoretical and practical background of the introduction, this study aims at addressing the following research question of 'how does "to what gender and status one talks" govern the speaker's strategy in keeping on their conversation?'

\section{Method}

\subsection{Sample / Participants}

The participants were from the educated males and females randomly, especially university students, from all the faculties of the State Islamic Institute of Surakarta, the only state Islamic institute in Surakarta. The data is based on three topical functional units in which the length of the data is defined by the completeness of the topic discussed by the speaker and audience which composed of 107 acts and 103 moves from three faculties to find out the different conversational strategies on the intersection among acts used, speaker-audience gender, status, and situation of conversation.

\subsection{Instrument $(s)$}

The researcher used observation aided by Audio recorder, as the main media, to ensure the researcher in collecting and protect his data. The data that is tape-recorded was changed into Wav Format by Audacity Software that is able to change the audio record to audio file. 


\subsection{Data collection procedures}

The audio file got from Wav Format by Audacity Software to see the voice accuracy because we can see the form of tone graphic that can be made slower or faster. These two ways were done to strengthen and record attitude of person when the conversation was ongoing. The audio record technique was done as follows: 1) the researcher was helped by one participant or more to record the ongoing conversation; 2) the research assistant was a person closed to the other participants, so it did not interfere the natural interaction; 3) the duration of recording depends on the finishing conversation about a certain topic or topical unit; 4) the conversation taken can be with or without elicitation, in the elicitation is done to trigger the conversation, until he gets a natural act, topic or situation on participants; 5) the recording tape data is transferred into Audacity Beta 1.3 software; 6) the transaction is classified based on faculty, exchange, move, and act; 7) the data transcript is orthographically presented, not the phonetically, as it was done by Sack and Jefferson (in Claymann 2013, pp.379, Komter, 2013, pp.617-626; Perakyla, 2013, pp.555-572).

\subsection{Data analysis}

The researcher analyzes speaker conversational strategy based on the gender role by using discourse analysis known as Birmingham Discourse Analysis Model (Sinclair and Coulthard 1975). This analysis model emphasizes to the spoken interaction, that is, the discourse hierarchy. They are five grades of the hierarchy: 'transaction', 'turn and its design', 'exchange', 'move', and 'act'. The first level of the hierarchy is of 'transaction' which is the conversational interactional activity among the students. It is composed of one or more exchanges. The second is 'exchange', that is, a pair of at least two turns by two different participants. The third is 'turn' which covers the turn taking of the conversational activity done by a certain participant before another participant takes the following turn. Turn is composed of one or more 'moves'. The forth is 'move' which covers the speech acts for initiating, responding, and following up the preceding speech. The fifth is 'act' which covers a speech function, that is, the smallest unit of the transaction used as the basic and first unit to analyze. 'Act' refers to verb groups of speech acts formulated by Leech (1983). Leech classifies speech acts based on the componential analysis from each act that makes the result is more applicable, accurate, and measurable. The following components are used in classifying the acts: 1) does the event happen after speaker's act?; 2) is the speaker or the listener involved in that event?; 3) if the event happens after speaker's act, is it compulsory to the listener or not?; 4) does the event give the benefit to the speaker? and; 5) what attitude implies?. The act implications are classified into five types in term of its attitude: a) assertives implying telling the belief about something/someone; b) directives implying making the listener do something or believing that something beneficial to the listener; c) commissives implying pushing, wanting, meaning that speaker do something, d) expressives implying that speaker is happy, regret, sympathy, sad, forgive, pride, thank over something; e) rogatives implying that the speaker is unsure over something. The analysis, then, is grouped based on the participant's faculty, in which there are three faculties as the subtopic of analysis. The faculties are Shariah and Islamic Economics Faculty, Ushuluddin and Dakwah Faculty, and Islamic Education and Language Faculty. The analysis covers: (a) making general tabulation which covers the conversational components: transaction, act, and move; (b) classifying the acts and moves based the gender and status of the participants in their conversation; (c) summing the frequency of each type of acts and moves based on gender and status; (d) making the aggregate acts and moves over the faculties based on the gender, status, and the type of acts done; (e) interpreting the use of the dominant types of act by certain gender of certain status in the conversation activity into assertive, directive, commisive, expressive, and rogative; (f) interpreting the moves based on the gender into: initiation, response, and follow-up. 


\section{Results}

\subsection{Cross gender conversational strategy of Islamic Education and Language Faculty Students}

\subsubsection{Description of context, topic, and participants of the conversation}

This formal conversation, table 1 below, discussed the evaluation of program held by student activity unit of Sirat Theater entitled Latihan Dasar Theater (Basic Theater Training) in Student Center at afternoon. Topic of the discussion was accommodation (meal) for the participants of the training and the whole evaluation of the programs in LaDa (basic training) like the committee, equipment, and the content of the material. Otherwise, the topical analysis unit is on accommodation (meal). The involved participants were M1 (male one) as the head of Sirat Theater and the moderator, F1 (female one) as accommodation coordinator of the committee, and M2, M3, F2, F3 as the members of the discussion. All the members of the committee were of the same semester, semester seven. M1 had the highest status, marked by M1+ one. F1 had higher status than M2, M3, and F2 and marked by F1+2 because status number 2 after $\mathrm{M} 1+1$. The mark + is used to indicate that the concerned has higher status.

Table 1. Data and tabulation of conversational speech components of cross gender formal conversation of Islamic Education and Language Faculty

\begin{tabular}{|c|c|c|c|c|}
\hline \multirow[t]{2}{*}{$\overline{\mathrm{G} / \mathrm{S}}$} & \multirow[t]{2}{*}{ Transaction } & \multicolumn{2}{|c|}{ Acts } & \multirow[t]{2}{*}{ Moves } \\
\hline & & Type & No & \\
\hline M1+ & $\begin{array}{l}\text { Selanjutnya bagia::an anu, logistik (0.5) mbak Mila, laporannya } \\
\text { bagaimana? } \\
\text { "Miss Mila how is the report of the accommodation?" }\end{array}$ & Ask & 1. & Initiation \\
\hline \multirow[t]{2}{*}{$\mathrm{F} 1$} & $\begin{array}{l}\text { Ya, kemarine wak, e::e pas LaDa kemarin, e::e petugas yang masak } \\
\text { itu, e ketuanya atau chef, master chefnya itu diketuai oleh e::e Pak } \\
\text { Dholi, terus dibantu oleh Rani, Jangkrik ama saya. } \\
\text { "In LaDa Training, the chef was Mr. Doli assisted by Rani and } \\
\text { me" }\end{array}$ & Answer & 2. & Response \\
\hline & $\begin{array}{l}\text { Untuk pembuat e::e untuk e::e masak-masaknya itu, e::e langsung } \\
\text { (0.5) langsung belanja, ke pasar, terus dimasak. Jadi belanjanya } \\
\text { satu kali untuk satu hari, gitu. } \\
\text { "Shopping to the market for the whole day was only once" }\end{array}$ & Announce & 3. & Initiation \\
\hline \multirow[t]{2}{*}{ M1+ } & $\begin{array}{l}\text { Hmm, } \\
\text { "Yes" }\end{array}$ & Assert & 4. & Response \\
\hline & $\begin{array}{l}\text { ada kendala apa biasane? Maksute laporan untuk laporannya, } \\
\text { "What is the usual handicap?" }\end{array}$ & Ask & 5. & Initiation \\
\hline \multirow[t]{3}{*}{$\mathrm{F} 1$} & $\begin{array}{l}\text { E::e kendalanya mungkin banyak gangguan, } \\
\text { "The handicaps were many" }\end{array}$ & Answer & 6. & Response \\
\hline & $\begin{array}{l}\text { Jadinya nggak, ngga::ak, nggak tertangani dengan mateng. } \\
\text { "The handicaps were not handled well" }\end{array}$ & Assert & 7. & \\
\hline & $\begin{array}{l}\text { Tapi malah sing saya suwe. } \\
\text { "Otherwise it took longer time" }\end{array}$ & Lament & 8. & Initiation \\
\hline M1+ & $\begin{array}{l}\text { Maksudnya?= } \\
\text { "What do you mean?" }\end{array}$ & Ask & 9. & Response \\
\hline $\mathrm{F} 1$ & $\begin{array}{l}=\text { Maksute } i \text { okeh sing do ngrumbyung tapi ki::i ora iso dadi= } \\
\text { "I mean there were many people participating but it was not } \\
\text { finished" }\end{array}$ & Answer & 10. & Follow up \\
\hline M2 & $\begin{array}{l}=\text { Tidak } \\
\text { "Not" }\end{array}$ & Allege & 11. & Initiation \\
\hline $\mathrm{F} 1$ & $\begin{array}{l}\text { [malah tambah suwe wektune.] } \\
\text { [it would take more time]" }\end{array}$ & Assert & 12. & Response \\
\hline M2 & $\begin{array}{l}\text { [Tidak bertanggung jawab] } \\
\text { "[not responsible]" }\end{array}$ & Demand & 13. & Follow up \\
\hline
\end{tabular}


$\mathrm{M} 1+$

O::o malah istilahe ngerusuhi?

"Oh otherwise were they disturbing?"

F1 Ha 'a::a okeh sing ngrusuhi $=$

"There were many"

M3 =Karepe ngewangi tapi malah ngrusuhi!

"They meant to support but, on the other hand, disturbed

F1

He'e::e

"He he"

M1+ Untuk menu, menu makanannya, Untuk hari pertama?

"What was the first day menu?"

F1 Menu makanan, untuk hari pertama::a kita buatkan::n bayem, tumis bayem sama tempe, yang malemnya, (0.5) kangkung sama tempe juga, terus hari kedua,

Hari kedua:: a itu, sawi, sawi putih tumis sama GEREH. PEYEK

GEREH, terus yang malemnya [::a

"The first day menu lunch were spinach, soybean cake, dinner water spinach and soybean cake, the next day tumis of china cabbage, fried dried-fish crackers, then dinner was...[“

"Lunch first"

F1

M1+ =Yo kuwi.

"Just the lunch"

[Sia::angnya itu!] =

"The lunch"

F1 Yang malemnya itu:: sambel terong sama::a tempe

"Dinner chilli sauce, eggplant, and soybean cake"

M1+ $\quad{ }^{\circ}$ Sambel terong sama tempe.

"Chili sauce, eggplant, and soybean cake"

Hari ketiga?

"The third day?"

F1 Hari ketiga::a e::e para e anggota LaDa yang baru kan itu, Answer ngamen Pak, jadinya::a=

"For the third day we would look for donation"

M1+ =Kendalanya Cuma::an malah kebanyakan personel malah Enquiry ngrusuhi gitu ya?

"The problem was that too many people, they would disturb us"

F1

[Iya.. iya ] semacam itu

Assert

"Ya ya... possibly"

M1+ Teru::us anu untu::uk anggota LaDa sendiri mengeluh nggak Ask tentang masakan-masakannya itu?

"Did the members of LaDa complain the meal?"

F1 O::oya mereka bilang enak, begitu Pak $=(($ confirming by facial Answer expression))

"They said delicious"

$\mathrm{M} 1+\quad=$ O::o enaa::ak, o berarti ya (0.5) logistik is [CLEAR] ya? Is Assert clear.

"O o delicious ya, ok accommodation is clear"

F1

M2

$\mathrm{F} 1$

F2

F3

M1+

Ask

14. Initiation

Answer

15. Response

Assert

16. Initiation

Assert

17. Response

Ask

18. Initiation

19. Response

Command

20. Initiation

Assert

21. Response

Assert

22. Follow up

Announce

23. Initiation

Assert

24. Response

25. Initiation

26. Response

27. Initiation

28. Response

29. Initiation

30. Response

31. Initiation

Assert

[OKE:]

Boast

32. Response

33. Initiation

"Because of the pressure, they said delicious"

$$
\begin{aligned}
& \text { [Hahaha] ((laughing)) } \\
& \text { [Hahaha] (( laughing )) } \\
& \text { [Hahaha] (( laughing )) }
\end{aligned}
$$

Assert

34.

Assert

Assert

Thank

Hahaha ya, terima kasih.

"Ha ha ha ya, thank you"

Ya buat itu tadi::i laporan dari logistik be [:rarti clear ya?] $y a$,
Assert
35. Response

37. Follow up

38. Initiation 
"For that report, was the accommodation clear?"

$\mathrm{F} 1$

M1+ Selanjutnya::a "What next...?" $\begin{array}{llll}\begin{array}{l}\text { [Ya lengkap,] clear! } \\ \text { "Clear" }\end{array} & \text { Assert } & \text { 39. } & \text { Response } \\ & \text { Ask } & 40 . & \text { Initiation }\end{array}$

Abbreviation:

G/S: Gender/Status, M: male, F: female, +: higher status

\subsubsection{Data description}

The act and move types in cross gender formal situation conversation in IELF of table 1 above show that male having highest status (M1+1) makes eight directive acts, mainly, to the females having lower status, those are, directive acts of ask (act 1, 5, 9, 14, 18, 25, and 29) and of command act 20 but rogative is done only once of enquiry, that is act 27 and assertive of assert four times (act 4, 22, 31, and 38). When he speaks to the same gender having lower status (M2), he makes only expressive act of thank once (act 37). On the other hand, M2 talking to higher status female $(\mathrm{F} 1+2)$ makes more directive acts also of demand once (act 13), of boast once (act 33), and only once of assertive act of allege (act 11). When she $(F 1+2)$, however, speaks to the same gender she makes more assertive acts of announce and answer for nine times (act 2, 3, 6, 10, 15, 19, 23, 26, and 30), of allege ten times (act 7, 12, 17, 21, $28,32,34,39,35$, and 36) and expressive act of lament once (act 8). Based on the move distribution, male makes more moves of initiations 12 times of 17, female makes only 5 times of initiations. Female makes 13 times response of 16, male only makes 3 times response. Male makes all the follow-ups in the conversation.

\subsubsection{Data interpretation}

Based on the description above it can be seen that higher status male in formal cross gender conversation makes more directive acts to the females. It means that male makes the females do something unconditionally (compulsorily), even low status male. On the other side, female makes more assertive acts regardless the gender and the status of her audience. This means that female makes most of her speech to express about herself to any gender and social status, what she knows and trust, in which she does not make her audience do something. Relating to the move of conversation, it can be seen that male makes much more initiation moves and all moves of follow up. Most of the female make only the response to the male. This means that male has more tasks in initiating and completing the conversation to any audience and the female continuing and responding the initiation of the male one. What female does is to firm the state of good relationship and her support to her audience of any gender and social status.

\subsection{Formal conversational strategy of Sariah and Islamic Economics Faculty (SIEF) students.}

\subsubsection{Description of context, topic, and participants of the conversation}

The conversation below happened in formal discussion session of the class among three Sariah and Islamic Economics Faculty students: M1, F1+, and F2+. M1 has two classmates of the seventh semester: F1 and F2 who had taken a course or subject of Sariah Law or Islamic law a year before. F1+ and F2+ are supposed to be so experienced and knowledgeable that she treats them having higher status than hers. They were discussing about the Islamic law for having marriage and trade. 
Table 2. Data and the tabulation of conversational components in formal cross gender conversation in Sariah Islamic Economics Faculty

\begin{tabular}{|c|c|c|c|c|}
\hline \multirow[t]{2}{*}{$\mathrm{G} / \mathrm{S}$} & \multirow[t]{2}{*}{ Transaction } & \multicolumn{2}{|c|}{ Act } & \multirow[t]{2}{*}{ Move } \\
\hline & & Type & No & \\
\hline L1 & $\begin{array}{l}\text { Hukum muamalah tu gimana ta mbak? Anunya } \\
\text { "How is the law of Muamalah Miss?" }\end{array}$ & Enquiry & 1. & Initiation \\
\hline $\mathrm{F} 1+$ & $\begin{array}{l}\text { Oh(0.5) aku gak tahu. Poko'e ya tentang hukum jual beli } \\
\text { "The point is the law of trade" }\end{array}$ & Announce & 2. & Response \\
\hline M1 & $\begin{array}{l}\text { Jual beli } \\
\text { "Trade" }\end{array}$ & Assert & 3. & Follow up \\
\hline $\mathrm{F} 1+$ & $\begin{array}{l}\text { Ha'a. Terus apa tu::u } \\
\text { "Yes, so what then" }\end{array}$ & Assert & 4. & Initiation \\
\hline M1 & $\begin{array}{l}\text { Kalau hibah-hibah itu? } \\
\text { "If it is a grant?" }\end{array}$ & Ask & 5. & Response \\
\hline $\mathrm{F} 1+$ & $\begin{array}{l}\text { Itu sama tu } \\
\text { "That is the same" }\end{array}$ & Answer & 6. & Initiation \\
\hline M1 & $\begin{array}{l}\text { Termasuk hukum muamalah juga kan? } \\
\text { "It is law of Muamalah also, isn't it?" }\end{array}$ & Enquiry & 7. & Response \\
\hline $\mathrm{F} 1+$ & $\begin{array}{l}\text { [He'eh..he'eh] tapi belum bahas itu. } \\
\text { "But we don't get the subject yet" }\end{array}$ & Announce & 8. & Initiation \\
\hline $\mathrm{F} 2+$ & $\begin{array}{l}\text { Belum nyampe } \\
\text { "Not yet" }\end{array}$ & Assert & 9. & Response \\
\hline $\mathrm{F} 1+$ & $\begin{array}{l}\text { Kalau yang HS kan tentang hukum-hukum keluarga. } \\
\text { "If it is Sariah Law, it deals much with family law" }\end{array}$ & Enquiry & 10. & Initiation \\
\hline M1 & $\begin{array}{l}\text { Kalau hukum-hukum per (0.5) nikahan itu yang sah } \\
\text { seperti apa ya mbak? Aku belum mudeng materi yang } \\
\text { kayak gitu. } \\
\text { "Then what is the law of marriage miss? I do't } \\
\text { understand such a kind of material" }\end{array}$ & Ask & 11. & Response \\
\hline $\mathrm{F} 1+$ & $\begin{array}{l}\text { Udah sah, kalau udah ada ininya ijab qabul } \\
\text { "It is legal if there has been ijab qobul (merriage } \\
\text { ceremony)" }\end{array}$ & Answer & 12. & Follow up \\
\hline M1 & $\begin{array}{l}\text { Terus mahar-maharnya itu biasanya berupa apa mbak? } \\
\text { "Then, usually, what kinds of bride-price?" }\end{array}$ & Ask & 13. & Initiation \\
\hline $\mathrm{F} 1+$ & $\begin{array}{l}\text { Biasanya kan kalau mahar itu kan permintaan dari si } \\
\text { ceweknya itu calon }\end{array}$ & Answer & 14. & Response \\
\hline & "bride-price is usually the request of the bride" & & & \\
\hline & O (0.5) trus apa ya, yang belum aku mudeng itu kalo & Enquiry & 15. & Initiation \\
\hline
\end{tabular}
melamar atau tunangan itu mbak, aku belum mudeng materi yang kaya gini. 
"Something I don't know is whether proposal and engagement are legal?"

\begin{tabular}{|c|c|}
\hline $\mathrm{F} 2+$ & $\begin{array}{l}\text { Sah sah aja } \\
\text { “legal also", }\end{array}$ \\
\hline $\mathrm{F} 1+$ & $\begin{array}{l}\text { Sah ta ada gak? } \\
\text { "Legal?" }\end{array}$ \\
\hline $\mathrm{F} 2+$ & $\begin{array}{l}\text { [ Piye?] } \\
\text { "How?" }\end{array}$ \\
\hline $\mathrm{F} 1+$ & $\begin{array}{l}\text { [emang ada,] he'ehhe ((laughing)) } \\
\text { hukum lamar-melamar emang ada } \\
\text { cuman kan tapi kan belum sah untuk } \\
\text { apa (0.5) melakukan (0.5) kaya seperti } \\
\text { suami istri itu belum sah, belum ada ... } \\
\text { "It is legal but they cannot do what the } \\
\text { husband and wife do, it is not legal } \\
\text { before ijab qobul" }\end{array}$ \\
\hline
\end{tabular}

F2+

$\mathrm{F} 1+$

He'eh belum sah

"It is not legal yet"

[harus ijab qabul,tanpa ijab,belum sah ya?]

[Melakukan

] "to do"

[ijab qabul.]

Ask

Enquiry

Announce
19. Follow up

16. Response

17. Initiation

18. Response

20. Initiation

21. Response

22. Initiation

apa(0.5)apa memang

kalau di dalam e islam itu

(0.5)kalau di Islam itu apa

kalau perkawinan harus

M1 pake ini, pake apa

namanya ,harus pake

seperangkat alat shalat itu

apa itu memang diwajibkan

mbak?

"In Islam it is compulsory to give bride-price a set of praying equipment?"

Iya, karena itukan $(0,5)$

23. Response

F1+ "yes, because it is the easiest one"

[lebih mudah],

Announce

24. Initiation

kan biasanya pakai

barang tunai

"It is usually cash, isn't it?"

Ehheh((deep breathing)) itu kaya seperti apa itu, rata-

Announce

25. Response

$\mathrm{F} 1+\quad$ rata kan kita orang islam jadinya kan sudah seperti kewajiban. 
"We are mostly muslim, so it seems as a compulsion"

M1 Udah, ini sebagai ini ya mbak?

"That is up, it has been a habit"

gitu..]

[Ho'oh kaya,]

F1+ kebiasaan he'eh kebiasaan adat

"Yes, it has been tradition"

Kebiasaan orang jawa itu terkenal

F2+

"The Javanese tradition is famous"

Kebiasan orang jawa juga, menggunakan seperangkat

F1+ alat shalat itu mentok.

"For the habit of the Javanese also, to use a set of praying equipment is maximal"

F2+

Minimalnya itu

"That is minimally"

F1+

Apa itu, kalau di arab-arab itu lebih (0.5) minta rumah,

"if it is in Arab, the bride will ask a house"

Berarti kalau di arab-arab itu pernikahanya, hukum syariahnya ya mbak,trus (0.5) berarti ini apa kalau di arab itu rumah- rumah kaya gitu, kalau di Indonesia kan seperangkat alat shalat setahu saya?

"So, in Arab law, Marriage is by house, in Indonesia is by a set of praying equipment"

$\mathrm{F} 1+$
Ha'a itu paling minimal itu

"Yes, that is minimally"
Assert

26. Initiation

Assert

27. Response

Announce

28. Initiation

Announce

29. Response

Assert

30. Follow up

Announce

31. Initiation

Assert

32. Response

Assert

33. Follow up

\subsubsection{Data description}

The data and tabulation of conversational components in formal cross gender conversation in SIEF in table above show that the lower status male makes more directive acts to the female, around four times (act no 5, 11, 13, and 22); besides three rogative acts of enquiry (act 1, 7, and 15) and three assertive acts of assert (act 3,26, and 32). When the higher status female speaks to the lower male she makes more assertive acts of announce and answer six times (act 2, 6, 12, 14, 23, and 31), of as sert three times (act 4, 27, and 33), as well as once of rogative. Such a kind of acts are also done to the same status female, the same gender, for which she makes assertive acts of announce four times (act 8, 19, 25, and 29) and twice of assert (act 9 and 21) followed by once directive act of ask (act 17). Assertive acts are also done between the same status females, F2+ to F1+, in which F2+ makes assertive acts of assert three times (act 16, 20, and 30) and of announce twice (act 24 and 28) as well as rogative act of enquiry once (act 18). Based on the move, male makes more initiations 9 times of 13 but female makes only 4 initiations. Female makes most of her moves in response to the initiations done by the male, 15 of 17 times of responses; male responds the initiations twice. All the moves of follow-ups are done by the femal.

\subsubsection{Data interpretation}

Based on the above description, it is known that generally the higher status female tends to make more assertive acts of announce, assert, and rogative acts to the lower female. On the other hand, the 
lower status male tends to make more directive acts than assertive and rogative acts. The crucial difference is that female avoids making directive acts to male, even the lower status male. Male makes more initiations that are responded by the female. Female makes all the follow-ups due to she has higher status than the male one.

Strategically the interesting one of this data is that male, even though having lower status than the female, keeps making more directives and initiations to the female of higher status. The higher status female permits male to dominate, initiate, and control the conversation.

\subsection{Formal conversational strategy of Dakwah and Ushuluddin Faculty students}

\subsubsection{Description of context, topic, and participants of the conversation}

The conversation of table 3 bellow took place formally and discussed the work plan which involved the committee of Racana Unit (Unit of Boy scotch Activity), at the office of Racana in student center building. The topic discussed was the activity, which had been done and would be done, mainly the boy scotch orientation. All of the participants were of the seventh semester students. M1 was the secretary of Racana of semester seven. M2 was the member of research and development unit of Racana. M3 was the chief of board in Male Unit Board of Racana. M4 was the member of empowering unit of Racana. F1 was the member of Boy Scotch Technique Unit of Racana. F2 was the chief of Female Unit Board of Racana. Organizationally M1 had the highest status in the conversation because he was the secretary of Racana and the leader of the meeting.

Table 3. Data and tabulation of conversational speech components of cross gender formal conversation of Dakwah and Ushuluddin Faculty

\begin{tabular}{|c|c|c|c|c|}
\hline \multirow[t]{2}{*}{ G/S } & \multirow[t]{2}{*}{ Transaction } & \multicolumn{2}{|c|}{ Act } & \multirow[t]{2}{*}{ Move } \\
\hline & & type & No & \\
\hline $\mathrm{M} 1+$ & $\begin{array}{l}\text { Eh (hh,hh,eh.heh.engh.henh) kalau untuk di lapangan } \\
\text { Rabu nanti saya cek Kamis saya garap ehh saya } \\
\text { harap kumpul lagi nanti saya berikan gambaran di } \\
\text { Segoro Gunung seperti ini seperti ini, Kemuning } \\
\text { seperti ini seperti ini. Kemudian Mungkin di lapangan } \\
\text { tembak seperti ini seperti ini atau dimana nanti saya } \\
\text { berikan gambaran pada hari Kamis kalau harus } \\
\text { menunggu sampai tanggal } 23 \text { acaranya terlalu apa } \\
\text { itu, terlalu jauh jadi Insya Allah minggu depan saya } \\
\text { akan laporkan itu. } \\
\text { "Eh on Thursday, I hope we all meet and I will inform } \\
\text { the profile of Mount Segoro. It is waiting too long if } \\
\text { the program is held on } 23 \text { th, may next week I report" }\end{array}$ & Promise & 1. & Initiation \\
\hline M2 & $\begin{array}{l}\text { Masuk! } \\
\text { "Come in”, }\end{array}$ & Recommend & 2. & Response \\
\hline M3 & $\begin{array}{l}\text { Gimana kalau bukan hari Kamis kita kumpul, Gimana } \\
\text { kalau hari sabtu? } \\
\text { "What do you think if we meet on Saturday, not } \\
\text { Thursday?" }\end{array}$ & Ask & 3. & Initiation \\
\hline
\end{tabular}


Jangan hari Kamis karena (0.5) kita ada empat mata kuliah yang diujikan filsafat Islam YA::A Kalau hari Sabtu?

"Don't take it on Thursday, we have four subjects tested, Islamic Philosophy, if Saturday?"

F1

Kalau hari Sabtu kan. Itu temen temen bagaimana gitu lho?

"If Saturday, what do you think friends?"

Kalau hari Sabtu banyak yang pada pulang (hh,hh,eh.heh.engh.henh) eeeg kalau dari Ketua rekannya sendiri hari Kamis keberatan bisa di ajukan ke hari Rabu.

"On Saturday, there are many friends going home, referring to the Head, if Thursday is refused, it can be rescheduled earlier on Wednesday."

F2

Kamis juga banyak yang=

Announce

"On Thursday, there will be="

$\mathrm{M} 1+\quad=$ Ya berarti Rabu

"Ya, clear, on Wednesday"

F2

Rabu

"Wednesday"

M1+

Gimana Rabu?

"What do you think on Wednesday?"

M2

F2

Ya Rabu, Rabu

"Ya Wednesday"

Berarti Rabu kan

"The deal is on Wednesday, isn't it?"

M3 Ya Rabu Rabu AH:::H

"Ya Wednesday Wednesday AH:::H”

M1+ Berarti kan kita jelasnya. Kaitannya tempatnya Pak Kalau ada masalah keuangan nanti ama bendahara ya ntar juga berarti

"OK we are clear. In relation to place Sir, if there is a problem relating to the finance, please come to the treasurer"

M4

Eee hh,hh,eh.heh.engh.henh tanggal tiga kita laporan di bank, tempat, sama waktu

"Ehh on the $3^{\text {rd }}$ we report to the bank, place, and time"

M1+ Sekarang bagi temen-temen yang kekurangan apa yang kurang yang belum jelas apa mungkin langung dilempar aja ke forum ini supaya kita

"For those who are not clear yet, it can be floored"

Assert

Assert

Ask

Answer

Enquiry

Command

Advise

Announce

Advise
Recommend

4. Response

Advise

6. Response

5. Initiation

8. Response

9. Follow up

10. Initiation

11. Response

12. Follow up

13. Initiation

14. Response

15. Initiation

16. Response 
" Reffering to the previous information, do we follow

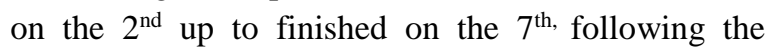
grouping of the members and we meet on the $9^{\text {th }}$ to decide whether we start as before or on the $19^{\text {th }}$ ?"

"What date?" sampai tanggal dua belas kita harus nanya tanggal enam belas

"Thanks God, as planned, it is on the $19^{\text {th }}$ untill the $12^{\text {nd }}$, and we have to ask the the $16^{\text {th }}$ ?"

"It is on the $2^{\text {nd }}$ till the $6^{\text {th }}$, isn't it?"

"On the $4^{\text {th }}$ “

Tanggal empat oo yaa monggo tanggal empat gak pa pa $(0,5)$

"Ok, please on the $4^{\text {th } ~ " ~}$

Tanggal empat hari Sabtu ya?

"The $4^{\text {th }}$ is on Saturday"

"On the $6^{\text {th }}$, the $7^{\text {th }}$, the $8^{\text {th" }}$

Ya kalau tanggal dua empat sampai tanggal empat gimana angkat tangan?

Answer

25. Initiation

"Ya if on the $24^{\text {th }}$ until the $4^{\text {th }}$, raise your hand?"

"Ya that is the only choice"

"Ya ya"

Ya berarti tanggal sembilan belas sampai tanggal empat, pertama yang kita pakai laporan bidang sudah.

"Ya so it is on the $19^{\text {th }}$ untill the $14^{\text {th }}$, firstly we use the report of each division"

selanjutnya belum, belum ada yang di lakukan cuma tuh. 
"Then no program has been done, hasn't it"

M2

$$
\text { Ya...ha...ha....hh,hh,eh.heh.engh.henh }
$$

"Ya ha ha ha... hh..."

$\mathrm{M} 1+$

F1

M1+

$$
\text { Heem gitu seharusnya. }
$$

"Heem, it should be"
Assert

Announce sudah bilang itu kita kan berangkat sama-sama.

"Yah, relating to the place, we are going together"

Nah, itu berarti kitA (0.5) gitu, terus perlengkapan itu kita nunggu dari tempat, berarti itu KRW yang bertanggung jawab penuh untuk yang lain perlengkapan, dia sudah bilang tadi YO tongkat udah sudah.

"So, the equipments we wait for the place, KRW is responsible for the equipments, he said stick are ok"

Bendahara penarikan uang penarikan pembayaran dari BK sama MARU, MARU ini nanti hari Senin baru kita omongin apa-apa saja yang akan kita pakai akan kita sebut akan kita bicarain ntar tunggu konfirmasi mereka juga kita nggak (0.5) kalau aku pribadi ntar $(0,5)$ supaya mereka juga lebih berpikir lebih ikut dalam perkumpulan itu tho? Nanti kita nanyain waktunya gimana? terus secara formalitas gimana?

"The finance of the treasurer is taken from BK and MARU, on Monday everything will be discussed and we wait for their confirmation, hopefully they join the meeting to be well informed? Later we ask the time? And how is it held formally?"
Assert

Assert

Enquiry

34. Initiation

\section{Response \\ 31. Initiation}

32. Response

33. Follow up

\subsubsection{Data description}

The above conversation is of four males and two females. Based on the table above, male having higher status makes more directives to either male or female. To female, he makes directive acts of advice (act 6,14,16) and to lower male he makes directive of recommend (act 4) and assertive of assert (act 28 and 30) and of commisive of promise and offer (act 1 and 25), and directive of ask twice (act 10 and 29). When the lower speaks to the higher, he makes directive of command once (act 13) and rogative of enquiry once (act 3) and assertive once. It means that lower status male also makes directive to the higher although rarely. When female speaks to male either to higher or lower status, she makes more assertive (act 7, 9, 19, 21, 32) than other acts.

In aggregate there are 14 initiations which are all done by the male either by the higher status male or lower ones. Female dominates the responses around seven responses of 14 responses done by two females and four males, and the rest is done by the lower status males. Females also dominate the followup moves, which are three of five follow-ups, the rest are done by the lower status male.

\subsubsection{Data interpretation}

The act and move above imply that male of the higher status in formal situation makes more directive acts to either female or male audiences. Directive acts are done only by the male speakers of either higher or lower status audiences. The higher females receive more assertive acts, mainly from females. 
Meanwhile female never makes directive acts to anyone but assertive, rogative, and commisive instead. The conversational strategy in moves of initiations is fully dominated by the male. The conversational strategy taken by the male is that he dominates the interaction by having more directives and initiations to the lower status participants, mainly the females. He makes more directives and initiations to female to maintain his being dominant and his higher social status along the interaction in cross gender conversation. The female maintains her being togetherness and support by having more responses and assertive, rogative, or commissive acts.

\section{Discussion}

The following table is the area of the acts and the moves distribution generated by the students of all the faculties.

Table 4. The mapping of the act and moves based on "to what gender and status one talks"

\begin{tabular}{|c|c|c|c|c|c|c|c|c|c|}
\hline \multirow{2}{*}{\multicolumn{2}{|c|}{$\begin{array}{l}\text { Parcipant/ Speech } \\
\text { Components }\end{array}$}} & \multicolumn{8}{|c|}{ To What Gender (To whom) } \\
\hline & & \multicolumn{4}{|c|}{ Speech Act } & \multicolumn{4}{|c|}{ Move } \\
\hline \multirow{5}{*}{ 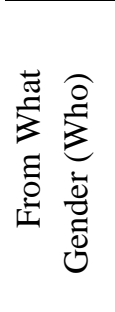 } & & $\mathrm{M}+$ & $\mathrm{M}$ & $\mathrm{F}+$ & $\mathrm{F}$ & $\mathrm{M}+$ & $\mathrm{M}$ & $\mathrm{F}+$ & $\mathrm{F}$ \\
\hline & $\mathrm{M}+$ & & $\mathrm{D}$ & $\mathrm{D}$ & $\mathrm{D}$ & & $\mathrm{I}, \mathrm{F}$ & $\mathrm{I}, \mathrm{F}$ & I, F \\
\hline & M & A & & $\mathrm{D}$ & $\mathrm{D}$ & $\mathrm{I}, \mathrm{F}$ & & $\mathrm{I}, \mathrm{F}$ & I, F \\
\hline & $\mathrm{F}+$ & A & A & & A & $\mathrm{R}$ & $\mathrm{R}$ & & $\mathrm{R}$ \\
\hline & $\mathrm{F}$ & A & A & A & & $\mathrm{R}$ & $\mathrm{R}$ & $\mathrm{R}$ & \\
\hline
\end{tabular}

The very interesting one in this study is that the acts of assertive (A), directive (D), and the moves of initiation (I), follow-up (F), and response (R) make their own cluster systematically. The acts and moves group accordingly to their types based on gender and status of the audience to whom one talks. The simple aggregate of the dominant frequency of the 107 acts and 103 moves in three functional topical units of conversation shows, based on the areas of each act in different types of alphabet table 4 above, that the higher male treats their audiences differently depending on the audience gender and status. $\mathrm{He}$ makes more directive acts to the lower status female. It means that, the interesting one, when the higher male converses to the females, he makes his female audience do something either compulsory or not, but when he speaks to the lower male he makes more assertive acts. The lower male behaves the same as the higher status male, making more directives, even, to the higher status female. However when he speaks to the higher status male he makes more assertive acts. Female makes more assertive to all audiences regardless the sex and the status of the audience. Female of higher or lower status makes assertive acts to the same gender. The higher female treats her audiences relatively the same in formal conversation of cross gender participants. This means that she only tells what he thinks and believes, like asserting, informing, answering, and enquiring. Moves of response are dominated by the female to any gender and status of her audience. Male makes more initiations and Follow-ups to all audiences. This means that male starts and initiates the conversation to whoever he talks. Male has more tasks in initiating and completing the conversation and the female continuing and responding the initiation of the male one. 


\section{Conclusions}

Male's acts directives and moves of initiation and follow-ups to female are to maintain his being dominant and his higher social status along the interaction in cross gender conversation. What females do in acts of assertive and moves of response are to firm the state of good relationship and to make clear of her being togetherness to the audiences. The culture and social value of conversation place the male to control and manage the conversation in formal situation. The strategy of conversation which is based on "to what gender and status one talks" is one of fields in materializing and actualizing their gender entities, mainly the social and cultural power of female and male. The result of this contextualized conversational study is limited to the three functional topical units taken from very limited area and needs be discussed for other areas of culture, language use, and social contexts.

\section{Ethics Committee Approval}

The authors confirm that this study does not need ethics committee approval. (Date of Confirmation: 12.03.2020)

\section{Acknowledgements}

This study was generated with the help of the observation assistant Mr. Wildan Mahir and the students of IAIN Surakarta.

\section{References}

Austin, J. (1962). How to Do Things with Words. Cambridge: Harvard University Press.

Baker, P. (2013). Introduction: Virtual Special Issue of Gender and Language on Corpus Approaches. Gender and Language, 1(1).

Baslow, S.A. and Rubenfeld, K. (2003). "Trouble Talks": Effect of Gender and Gender-Typing. Sex Roles, 48(2/4).

Carli, L. L. (1990). Gender, Language, and Influence. Journal of Personality and Social Psychology, 39(3), pp. 941-931.

Coates, J. (2004). Women, Men, and Language. London: Longman.

Eakins, B. W. and Eakins, R. (1978). Sex Differences in Human Communication. Boston: Houghton Milfflin.

Erickson, B. Lind, E. A., Johnson, B. C., and O’Barr, W. (1978). Speech Style and Impression Formation in a Court Setting: The Effects of Powerful and Powerless Speech. Journal of Experimental Social Psychology, 14(2), pp. 266-279.

Gill, V.T., \& Maynard, D. W. (2006). Explaining Illness: Patients' Proposals and Physicians responses. In J. Heritage \& D.W. Maynard (Eds.). Communication in Medical Care: Interaction between Primary Care Physicians and Patients (pp. 115-150). Cambridge: Cambridge University Press.

Giyoto. (2013). Sociolinguistics Measure For Paternal Gender Dominance Over maternal One Among Javanese Muslims. International Journal of Science and Research (IJSR), 2(3).

Gunnarsson, B. (1997). "Women and men in the academic discourse community". In Kotthoff, H. and Wodak, R. (Eds.), Communicating gender in context. Amsterdam: John Benjamins. 
Holmes, J. and Meyerhoff, M. (2003). The Handbook of Language and Gender. Oxford: Blackwell Publishing Ltd.

Itakura, H. (2000). "Describing conversational dominance”. In T Stivers, J, Steensig \& 1. Mondada (Eds.). The Morality of Knowledge in Conversation (pp. 29-57). Cambridge: Cambridge University Press.

Lakoff, R. (1975). Language and Women's Place. New York: Harper and Row.

Leech, G. (1983). Principles of Pragmatics. New York: Longman Group Limited.

Myaskovisky, L., Unikel, E., and Dew, A. (2005). Effect of Gender Diversity on Performance and Interpersonal Behavior in Small Work Groups. Sex Roles, 52(9/10).

Nyamekye, E. and Yarney, S. (2015). Social and Cultural Perceptions on Women's Education RW and Physical Embodiment on Their Ability to Wield Power over Men: The Yendi Experience in Northern Ghana. International Journal of Gender and Women's Studies, 3(2), pp.143-155.

Perakyla, A, Antaki, C., Vehvilainen, S. \& Leuder, I. (2008). Conversation Analysis and Psychotherapy. Cambridge: Cambridge University Press.

Searle, J. R. (1969). Speech acts: an essay in the philosophy of language. London: Cambridge University Press.

Sidnel, J. and Stives, T. (1969). The Handbook of Conversation Analysis. West Sussex: Wiley Balckwell Publishing.

Sinclair, J. McH \& Coulthard, R. (1975). Towards an Analysis of Discourse: English Used by Teachers and Pupils. Oxford: Oxford University Press.

Smith, L., and and Dykann, A. (2010). Do Men Speak The Same Language Differently? Investigating the effect of Gender and Language Use. University of Colorado Boulder.

Stevens, K, Lehmann, N. (2008). Battle of the Sexes: Differences in Directness of Communication between Men and Women in a Group Situation. Capital University's Undergraduate Research Journal, 3.

Swacker, M. (1979). “Women”s Verbal Behavior at Learned and Professional Conferences'. In Dubois, Betty-Lou and Crouch, Isobel (Eds.). The Sociology of the Languages of American Women. San Antonio: Trinity University.

Tannen, D. (1990). You Just Don't Understand: Women and Men in Conversation. New York: Ballantine.

Tannen, D. (1994). Gender and discourse. Oxford: Oxford University Press.

Tannen, D. (1995). Gender and Conversational Interaction. Oxford: Oxford University Press.

Wardhaugh, R. (1993). An Introduction to Sociolinguistics. Oxford: Blackwell Publisher.

Wheelan, S. A. and Verdi, A. (1992). Differences in Male and Female Patterns of Communication in Groups: A Methodological Artifact? Sex Roles, 27(1/2).

Zimmerman, W. and. (1983). "Small insults: A study of interruptions in cross-sex conversations between unacquainted persons". In Barrie Thome, Cheris Kramarae and Nancy Henley, (Eds.), Language, gender and society. Cambridge: MA Newbury House.

Zimmerman, W. and. (1998). “Women"s place in everyday talk: reflections on parent- child interaction'. In Coates, Jennifer (Eds.). Language and Gender: A Reader. Oxford: Blackwell. 


\section{Konuşmacının konuşmalarını sürdürme stratejisini "hangi cinsiyet ve statüden bahsediyor" nasıl yönetiyor?}

\section{Öz}

Konuşmacıların konuşmalarında kültürel ve sosyal açıdan kabul edilen stratejilerine karar vermelerinde "hangi cinse ve sosyal statüye" karşı konuştukları konuşmacının kimliğinden daha çok hâkim olur. Bu kulenin pilotun iniş stratejisini belirlemesine benzer. Konuşma analizi hakkimdaki bu makale Müslümanların resmi konuşmalarında izleyicilerin cinsiyet ve sosyal statüsünün konuşmacının konuşma eylemi ve hareketlerini nasıl belirlediğini güçlü, görevlendirici, vurgulayıc1, kibar 107 talimattan oluşan üç fonksiyonel konuya bağlı ünitede ve 103 başlatma, yanıt ve takıp eylemiyle anlatıyor. Bulgular tüm kadın öğrenciler için kendi sosyal gücünü daha fazla emredici eylem ve başlatma hareketi kullanarak konuşmayı bir erkeğin başlattığı ve kontrol ettiğini gösteriyor. Yüksek statüdeki kadın karşısında düşük erkek onaylayıcı veyanıtlayıcı olurken kadın konuşmacılar dinleyicileri cinsiyet ve sosyal statüsünün bakmaksızın iletişim ve sosyal beraberliği korumak için onaylayıcı eylerler ve yanıtları kullanıyor. Bulgular konuşma stratejisini tanımlamaktan çok kimin konuştuğunun dah çok hayati önem taşıdığına işaret ediyor.

Anahtar sözcükler: hangi cins ve statüye; kontrol; konuşma; strateji; materyalizme; güç

\section{AUTHOR BIODATA}

My high school until doctor program is of social science and language area and always the best graduate. The 21 books and 15 journal articles I wrote covered linguistics, sociolinguistics, gender and language, language teaching methods. I was the Dean of Islamic Education and Teacher Training Faculty of IAIN Surakarta around eight years and now the Dean of Cultures and languages faculty since January 2019 